\title{
The Effect of Concentration Calcium Alginate On Metformine Encapsulated
}

\author{
Sari Edi Cahyaningrum \\ Department of Chemistry \\ Universitas Negeri Surabaya \\ Surabaya, Indonesia \\ saricahyaningrum@unesa.ac.id \\ Amaria \\ Department of Chemistry \\ Universitas Negeri Surabaya \\ Surabaya, Indonesia
}

\author{
Nuniek Herdyastuty \\ Department of Chemistry \\ Universitas Negeri Surabaya \\ Surabaya, Indonesia \\ Pupuh Findia \\ Department of Chemistry \\ Universitas Negeri Surabaya \\ Surabaya, Indonesia
}

\begin{abstract}
This research aimed to study the effect of concentration calcium alginate on metformine encapsulation processes and investigated characteristic of metformine encapsulation. The encapsulation of metformine performed using chitosan and calcium alginate polymers with calcium chloride as crosslink agent. The concentrations of calcium alginate were varieties $0.5 \% ; 1.0 \% ; 1.5 \% ; 2.0 \% ; 2.5 \%$; and $3.0 \%(\mathrm{w} / \mathrm{v})$. The results showed that the highest encapsulation efficiency of metformine on concentration of alginate $2.0 \%$ $(w / v)$ and the lowest in the alginate $0 \%(w / v)$, respectively by $80.51 \%$ and $55.94 \%$. Encapsulation resulted with the highest the spectra FTIR analysis showed that there is vibration in 1497.91 $\mathbf{c m}^{-1}$ that indicated interaction between the carboxyl functional group of alginate and the amine functional group of chitosan
\end{abstract}

Keywords-Encapsulation, metformine, Alginate,

\section{INTRODUCTION}

Metformine represent drug of diabetes mellitus that is consumed by goodness patient of type diabetes 1 and also type 2 [1.2]. Metformine is permeated by digestive system better and has biologist bill time is short is around 2-5 hours [3]. Biologist bill time drug is short because patients have to consume drug of continuously. Most important side effects of this drug are acidosis of lactate acid. To lessen consumption side effects medicines with high dose and short bill time of drug done by development of drug control release system more beneficial. Because this system can to improve therapy effectiveness and to lessen side effects, and lessen dose. Drug control release system was syntheses by using natural polymer with method of encapsulation. This method is used to trap active component and discharging it was below condition of controlled. Some materials have been encapsulated in food industry and pharmacy, for example, amino acid, vitamin, mineral, antioxidant, colorant, sweetener and enzyme [4]. Polymer that most be used at application of encapsulation poliglicolida, guam gum, chitosan, alginate, and selulose acetate[ 5] In system carrier of drug, polymer like chitosan and alginate a more regular used because both having the character of is not toxic, biocompatible and good biodegradable]. Encapsulation of ketoprofen have been done with concentration variation of chitosan, alginate, and TPP as agent fasten to traverse can influence the amount of formed nanopartikel, efficiency of encapsulation, and particle size measure [6]. Pursuant to the mentioned hence at this study is studied about influence of concentration of alginate to metformin encapsulation.

\section{METHOD}

Some instrument that use in this research there are spectrophotometer UV-vis and SEM. Some materials with pro analysis that use are acetic acid, $\mathrm{CaCl}_{2}, \mathrm{AgNO}_{3}, \mathrm{NaOH}$, $\mathrm{K}_{2} \mathrm{HPO}_{4 \cdot 2} \mathrm{H}_{2} \mathrm{O}, \mathrm{NaOH}$

\section{A. Encapsulation of metformine on alginate chitosan} Metformine which have been attenuated to be enhanced by alginate with concentration $0,5 \% ; 1,0 \% ; 1,5 \% ; 2,0 \% ; 2,5 \%$; and $3,0 \%(\mathrm{~b} / \mathrm{v})$. The solution was mixing with magnetic stirrer until homogeneous, after that condensation dripped into $\mathrm{CaCl}_{2} 0.15 \mathrm{M}$. And then filtered and cleaned with aquades until $\mathrm{Cl}^{-}$lose, later then soaked in chitosan $0,1 \%$ $(\mathrm{b} / \mathrm{v})$ during 10 minute, filtered and dried at room temperature.

\section{B. Efficiency of encapsulation}

About 10mg metformine encapsulated on alginate-chitosan dissolved into $10 \mathrm{~mL}$ phosphate buffer $\mathrm{pH}$ 7.4. Mixture with stirrer magnetic until homogeneous at room temperature, after that was centrifuge at $6000 \mathrm{rpm}$ on speed during 30 minutes. The supernatant analyzed with spectrometer UVvis at wavelength $268.50 \mathrm{~nm}$.

\section{RESULT AND DISCUSSION}

The encapsulation processes was aim to entrap metformine use natural polymer alginate and chitosan. Both of these polymers have characteristics biocompatible, biodegradable, and not toxic. At this research is also used $\mathrm{CaCl}_{2} 0.15 \mathrm{M}$ as crosslink agent.

Usage of $\mathrm{CaCl}_{2}$ with low concentration so that do not happened bond $\mathrm{Ca}^{2+}$ with carboxilate from alginate because is ever greater of concentration of alginate hence will more and more tying. Metformine and solution of alginate was 
homogenized to use stirrer magnetic with comparison mixture 1:2 (b / b). After encapsulated, metformine encapsulated was analysis with FTIR for analysis functional group.

Result analysis of functional group from chitosan; chitosan-alginate; metformine and chitosan-alginatemetformine-tween 80, represented at Figure 1

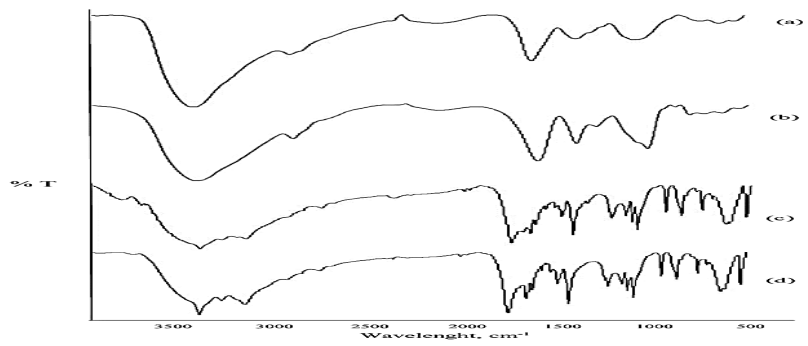

Fig. 1. Spectra IR of chitosan (a), alginate (b) dan chitosan-alginate (c) metformine; chitosan-alginate-metformine-tween 80 (d)

Chitosan and alginate have some characteristics spectra, existence of functional group $-\mathrm{NH} 2$ and $-\mathrm{OH}$ from chitosan shown by absorption in wave number $3444.03 \mathrm{~cm}^{-1}$, supported by vibration of N-H in wave number $1639 . \mathrm{cm}^{-1}$. The spectra at wave number $1639.21 \mathrm{~cm}^{-1}$ show the existence of functional group $-\mathrm{NH}_{2}$ chitosan. Existence of functional group of $\mathrm{C}=\mathrm{O}$ of alginate shown by keen absorption band at wave number $1622.72 \mathrm{~cm}^{-1}$, and existence of functional group of $\mathrm{C}-\mathrm{O}$ ester posed at strong absorption in wave number $1037.07 \mathrm{~cm}^{-1}$. The absorption show functional group - COO- of alginate. Existence of bunch of $\mathrm{C}=\mathrm{O}$ at wave number $1717 \mathrm{~cm}^{-1}$, and functional group of $\mathrm{CO}$ emerge at wave number $1165.96 \mathrm{~cm}^{-1}$ with low intensity, its meaning of functional group $\mathrm{C}-\mathrm{O}$ of alginate a lot have bond with $\mathrm{Ca}^{2+}$ as crosslink agent of functional group - $\mathrm{COO}$ [7]. Absorption at wave number $1437.09 \mathrm{~cm}^{-1}$ show to be formed is salt of carboxilate, its meaning there is interaction between functional group $-\mathrm{NH}_{2}$ chitosan and $-\mathrm{COO}$ alginate that is interation of polielectrolite complex

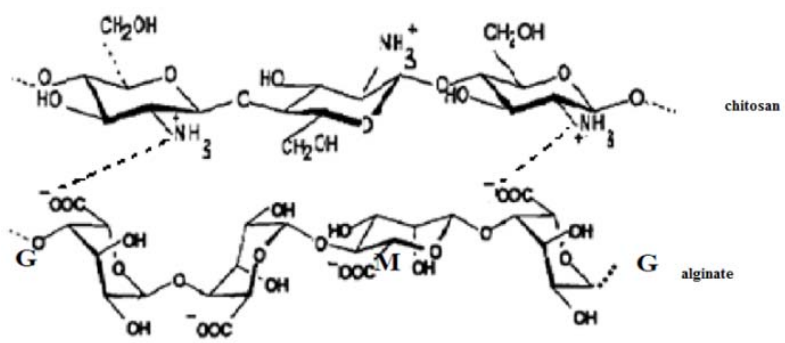

Fig. 2. Hipothetics Reaction of Chitosan-alginate

efficiency of Encapsulation represent examination to know rate metformine which trapped in polymer and alginate of chitosan Efficiency of encapsulation metformine in matrix presented in Table 1.

\begin{tabular}{|l|l|l|l|l|l|l|}
\hline $\begin{array}{l}\text { Composi } \\
\text { ton } \\
\text { chitosan } \\
\vdots \\
\text { metform } \\
\text { e }\end{array}$ & \multicolumn{6}{|c|}{ [alginate] \% (b/v) } \\
\cline { 2 - 7 } & 0,5 & 1,0 & 1,5 & 2,0 & 5 & 3,0 \\
\hline $1: 1$ & 65 & 67 & 70 & 68 & 65 & 63 \\
\hline $1: 125$ & 70 & 72 & 73 & 72 & 68 & 65 \\
\hline $1: 1,5$ & 75 & 78 & 80 & 78 & 75 & 73 \\
\hline $1: 2$ & 70 & 73 & 75 & 73 & 71 & 70 \\
\hline $2: 1$ & 60 & 62 & 65 & 62 & 60 & 57 \\
\hline
\end{tabular}

Tables 1 showing result efficiency encapsulation of metformine at alginate-chitosan. At results of analysis known that efficiency encapsulation influenced by concentration used alginate. At Tables 1 indicating that happened the value of efficiency of encapsulation along with variation of alginate concentration, but experiencing of degradation at concentration of alginate 2.5 and $3.0 \%,(b / v)$. This matter is caused because is ever greater of concentration of alginate hence will more and more tying among functional group of carboxilate of alginate with ion of $\mathrm{Ca}^{2+}$ and also with amine from chitosan. More and more tying it hence structure tying will be complicated progressively which resulting smaller pore formed so that cause degradation porosity. Pursuant to data analysis efficiency highest encapsulation is equal to 80 $\%$. Ever greater of concentration of alginate hence will more and more tying that happened with $\mathrm{Ca}^{2+}$ as crosslink agent, so that gel becoming stiffer and strength of its mechanic will be ever greater because tying progressively. But concentration of alginate which too high can cause drug molecule will progressively difficult to be quit of of them [8], form microsfere is concentration with high alginate tend to to experience of degradation of porosity so that can prevent trapped to metformine escape again $[9,10]$. 


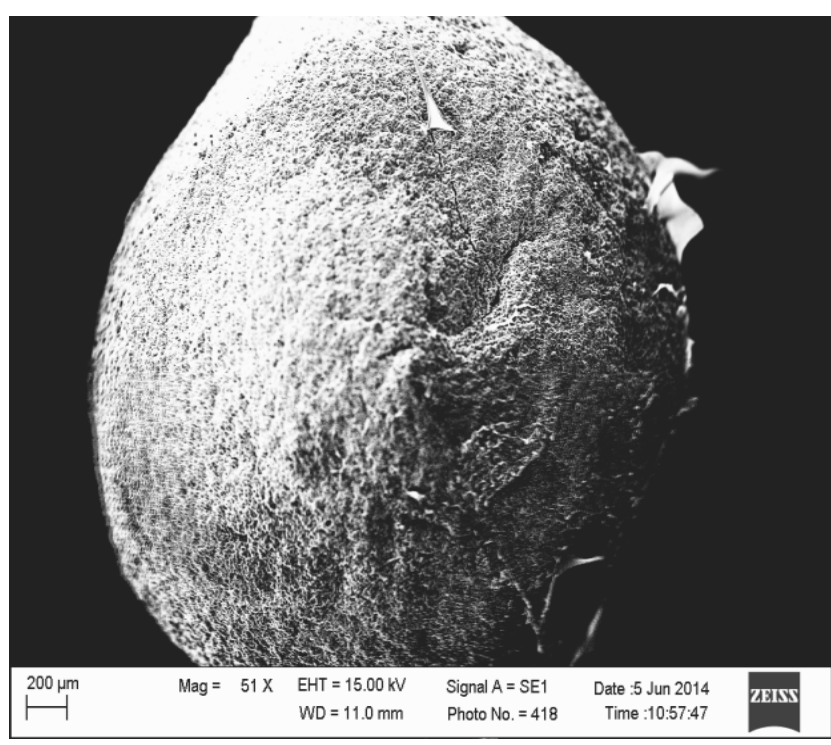

(A)

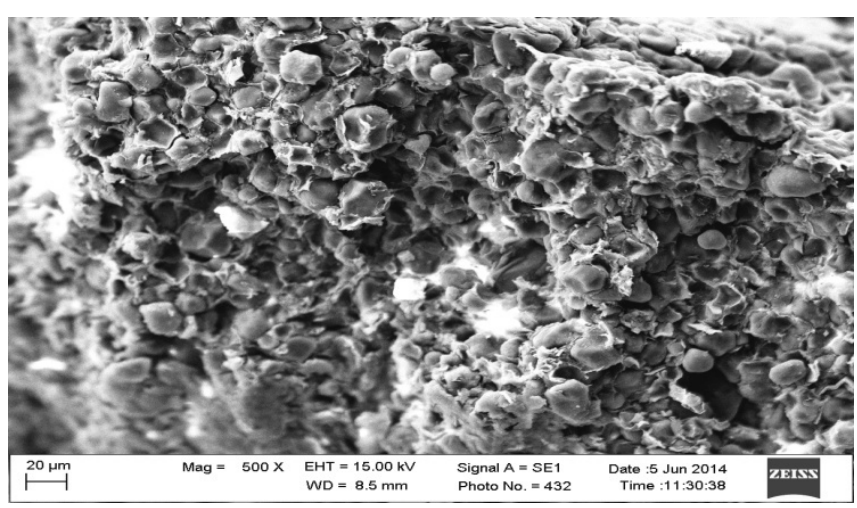

(B)

Fig. 3. SEM images of metformine encapsulated 100x (A) and 2000x (B)

Fig.3 The morphology surface of metformine encapsulated At Fig. 3 showed that surface morphology of metformine encapsulated seen surface of small granulated which is without agglomeration while surface of uniform circular granulated and its surface of refinement so that peaceful for digestive system.

\section{CONCLUSION}

Concentration of alginate influence efficiency value of encapsulation that is is ever greater concentration of alginate hence is ever greater [of] value efficiency of encapsulation, but efficiency highest enkapsulasi at usage of alginate equal to $1.5 \%(\mathrm{~b} / \mathrm{v})$ that is equal to $80 \%$ and lowest [at usage of alginate $3.0 \%(\mathrm{~b} / \mathrm{v})$ that is $57 \%$. Ever greater of concentration alginate can degrade porosity result of encapsulation causing metformine which is slimmer encapsulated. Analysis functional group showed the existence of bunch interaction - COO- alginate with $\mathrm{Ca}^{2+}$ as crosslink agent.

\section{ACKNOWLEDGMENT}

The researcher wishes thank you very much to DRPM DIKTI for funding support this research with Hibah Penelitian Dasar Unggulan Perguruan Tinggi, 2019.

\section{REFERENCES}

[1] V. K. Kamboj, and P. K.Verma, "Preparation And Characterization Of Metformin Loaded Stearic Acid Coupled F127 Nanoparticles," Asian Journal Of Pharmaceutical And Clinical Research vol 11, no. 8, pp.1217, 2018

[2] V.S.Devi, Aishwarya, B. Anbarasan, Narayanan, S. Sriman, and S. Ramaprabhu, "Optimization, Characterization and In-Vitro Studies of Pyrazinamide Loaded Chitosan Encapsulated on Gold Nanoparticles by Ionic Gelation Method". International Journal of Health and Pharmaceutical Sciences. 2(2): 8-20, 2013.

[3] R.Pandey, and G.K.Khuller, "Chemotherapeutic Potential of AlginateChitosan Microsphere as Anti-Tubercular Drug Carriers". Journal of Antimicrobial Chemotherapy. Vol 53, no.4, pp. 635-640, 20014

[4] C.Prieto, and L. Calvo, 2013. "Performance of the Biocompatible Surfactant Tween 80 for the Formation of Microemulsions Suitable for New Pharmaceutical Processing". Journal of Applied Chemistry, pp 1-10, 2013

[5] P.Sabitha, J. Ratna, and K .Reddy, Ravindra, "Design and Evaluation of Controlled Release Chitosan-Calcium Alginate Microcapsules of Anti Tubercular Drugs For Oral Use". International Journal of ChemTech Research. Vol.2, no.1, pp88-98, 2010

[6] M.N Mohamed, M.A Khaleid and S.Mohamed, "Formulation and evaluation of extended release metformin hydrochloride bead,". Int $J$ Pharm Pharm Sci, vol.6, 433-41, 2014

[7] F.M Monther, S.A Inam, and K.J Najwan, "Design, synthesis and preliminary pharmacological evaluation of new metformin derivatives,". Int J Pharm Pharm Sci ;vol.9, pp 279-93., 2017

[8] V.Mokale, R. Rajput, J.Patil, S. Yadava,and J, Naik," Formulation of metformin hydrochloride nanoparticles by using spray drying technique and in vitro evaluation of sustained release with 32-level factorial design approach,”. Dry Technol , vol 34, pp 455-61, 2016

[9] D.T Birnbaum, J.D Kosmala, L,Brannon-Peppas ,"Optimization of preparation techniques for poly(lactic acid-co-glycolic acid) nanoparticles,". J Nano Res , vol.2, pp.173-81, 2000.

24. S. Jain S Saraf, .'Influence of processing variables and in vitro characterization of glipizide loaded biodegradable nanoparticles. ,'Diabetes Metab Syndr Clin Res Rev, vol 3, pp.113-17, 2009 